\title{
Towards an Emotionally Conscious Social Theory
}

\author{
by Benet Davetian \\ The University of Prince Edward Island, Canada
}

Sociological Research Online, Volume 10, Issue 2,
< http://mww.socresonline.org.uk/10/2/davetian1.htm/>
doi:10.5153/sro.1082

Received: 26 Jan 2005 Accepted: 13 Jun 2005 Published: 30 Jun 2005

\begin{abstract}
This article attempts to contribute to the on-going discussion regarding the 'future of sociology and social theory' by suggesting that classical and contemporary social theories have yet to provide satisfactory accounts of the emotional components of human society. Following a discussion of how emotions have been downplayed in classical and contemporary theory, evidence is presented in support of a sociology that would include the study of emotions as part of broader studies of the social. A central proposition of this article is that the harmonization of studies of 'micro' and 'macro' realities would facilitate the development of a systems theory that neither excludes diversity nor minimizes the immutable emotional needs of individuals and their social systems. In support of the above argument, the author presents some new evidence pointing to the primacy of the human emotions across cultural boundaries.
\end{abstract}

\section{Keywords: Social Theory, Sociology of Emotions, Self, Identity, Micro, Macro, Postmodernism.}

\section{Introduction}

1.1 The recent discussions initiated by Nicholas Gane (Gane, 2004; Beer and Gane, 2004) regarding the 'future of social theory' are necessary and refreshing. We do need to evaluate on what has been accomplished during a century of social theorizing and reflect on the risks and opportunities faced by the discipline at a time of fragmentation and reorganization.

1.2 In this article I would like to try and make a contribution to this ongoing discussion by sharing some thought-provoking empirical evidence that points to the wisdom of further developing and refining a sociology of emotions and a manner of social theorizing that is 'emotionally perceptive.' While considerable work has recently been done in the area of emotions and embodiment, we continue to need some credible reconciliation between cognitive and biological explanations of agency and social behaviour. In the remainder of this article I will review some of the work that has been done, point to some continuing difficulties and then present some new evidence that suggests further ways in which we might develop a theory of the social that is relevant at the micro as well as macro levels.

\section{The Disembodied Science}

2.1 John Scott's Reflections on Disciplinary Fragmentation (2005) is a sobering reminder of the dangers as well as opportunities facing a social science that, although no longer governed by a strict and bounded canon, is in need of coherence and a curriculum capable of turning out graduates who possess a wellrounded 'sociological imagination.' Although Auguste Comte's conception of a 'queenly' social science no longer earns our credulity, there is much to be said about preserving a distinctly sociological way of observing and imagining the world. What needs to be discussed, however, is what is to be this 'sociological' frame of mind and how are we to fulfill the original promises of sociology within a contemporary context.

2.2 The task is not an easy one, partially because social theorizing is being continuously challenged by a contemporary social whose identity is complicated by decentralization, diversity, shifting boundaries and competing identity claims, but, even more importantly, because of certain troublesome omissions made by the founders of our discipline. Because of these omissions, we have been engaged in a debate in which the analytical parameters set for us by the founders have misaligned us vis-à-vis the people whom we are supposed to be studying. Social theory continues to suffer from a long-standing exclusion of the rich world of human psychology, an area that Comte assigned to the biological sciences, thereafter forcing 
2.3 Ever since the passing of Comte, we have been trying to locate this entity called 'society,' thought to somehow be metaphorically compatible with a geodesic dome, dependent on its individual parts, yet possessing a bearing and identity that surpasses and eclipses the individual identities of its modules. Prohibited from studying the social at its rawest microscopic level, Durkeim was left with no choice but to show that society was a force-field that pre-dated human sentiments and interaction rituals ([1895] 1982). While he made a commendable effort to show the consequences of loose and tight social bonds, the body of work he produced erred on the side of limiting the passion and power of human agency in favor of a 'suigeneric' social entity. Emotions were considered by Durkheim, but only in as far as they contributed to solidarity, distancing and hierarchies in macrosocial structures (Hammond, 1983).

2.4 Even Weber, who recognized the importance of human interactive processes, became pre-occupied with explaining the historical and religious origins of modern rationalization (1930). As a result, he minimized important intervening emotive movements that had a seminal influence on the development of capitalism and consumption in the West (i.e. The Age of Sensibility and the Romantic Movement) (Campbell ([1987] 1993; Dekker, 1978; Davetian, 2000a, 2005). Georg Simmel somehow compensated through his interest in 'sociability,' yet even his observations of emotions were made from the sidelines, based on studies of small groups rather than studies of individual biographies ([1908] 1950).

2.5 Bryan Turner $(1984,1992)$ and Chris Shilling (1993) have argued against this stubborn Cartesian dualism that has spared none of the social sciences from the illusion that the mind and body (society and person?) are separate. Anthony Synnott has also noted that, because of dualism, the project of building an embodied social theory remains very much an unfinished project (1993). The Cartesian split has provided a very seductive proposition that has contributed to the separation of sociology and psychology. It posits that the only thing that can stand outside of the illusions of thought and physical sensation is the person's ability to think (Descartes, 1968: 103). The manner in which Descartes sectioned off a 'reliable' part of consciousness created the illusion that the human being is graced with an extraordinary faculty that stands independent of their feeling experiences and the body social in which those experiences take place. It created the impression that a person could be an 'individual' while standing outside their embodied role in the social and outside their body's emotional reactions to that social. The trap was set for social theorists: they had to go to the other end of the spectrum and argue that the self was a unified experience of a 'suigeneric' body social.

2.6 The Cartesian disembodiment of the social system and the minimizing of the emotional motivations and bodily reactions of social actors have left theorists with no recourse but to study the world through a dubious inferential process. This has muddled the distinction between the social (institutional) self as social object-participant and the embodied (private) self as a thinking-feeling subject. It has also limited our understanding of the extent to which 'language/ideology' and 'voluntary/involuntary physiologically-activated emotions' are regulated and affected by personal as well as collective biographies. It should not come as a surprise that so many other disciplines--- including communications studies, journalism, documentary film, social psychology and cultural studies---are now daring to walk on grounds left untouched by a 'disciplined' sociology anxious to carve out a turf particular to itself while side-stepping extra-curricular information vital for its coherence and survival.

2.7 I am suggesting that the feared word in sociology---'psychologism'---is possibly the long-lost grail of the field. My purpose is not to suggest that emotions provide social actors with an extraordinary power of agency, nor that all social realities are emotionally bounded, but to encourage further debate on the nature of our emotional/social selves. Without this integrated understanding of the deep-core private self of the social actor we are left discussing the self in categorical terms: the self as reflexive entity, the self as thought, the self as an identity, the self as body, the self as a mirror, the self in modernity, the self as the other, the self as a transnational conduit. While these categorical abstractions help us understand larger shifts in the contours of the social, they leave us unable to evaluate the positive and negative effects of social change and, consequently, deprive us of the opportunity of developing social theories that not only explain current trends but also influence social change in accordance with the authentic needs of social actors.

2.8 It took one of history's most norm-challenging movements (the cultural rebellion of the 1960's) to make sociologists take note of a new emerging emotional landscape. Anthony Giddens made a commendable retrospective effort to understand the emotional components of the cultural transformations of the 1960's1980 's in Modernity and Self-Identity ([1991] 2001) when he noted that individuals were increasingly given to searching for 'pure relationships' that ministered to their needs for authenticity and emotional gratification. Earlier, Richard Sennett had remarked on this trend towards non-material gratification by calling it an 'oppositional culture' (1977). And, Arlie Hochschild (1975) and Theodore D. Kemper (1978) had argued for an emotionally informed sociology in the wake of a post-1960's emotive population demanding satisfactions 
2.9 For the most part, however, theorists struggling with the ghost of doctrinaire Marxism, abandoned the search for some stable definition of what it is to be human and concentrated instead on archiving a series of 'truths' capable of accommodating competing claims. Although this viewpoint helped debunk the constraints and normative influences of authoritarian prescriptions, its in-built a-priori skepticism towards absolute statements made us downplay the immutability of a major player in social life: the human body and the important and absolute role played by human emotions in social outcomes.

2.10 The question, 'What makes people tick and what effect does this have on the social?' may have been a rather limiting question for theorists pre-occupied with making sense of a variety of new social movements. Many settled for J. F. Lyotard's declaration that the self is a communicational reality (Lyotard 1999), a proposition that, in an ironic way, was mundanely compatible with the classical propositions of consensusoriented American pragmatists such as Herbert Mead (1934 [1967]) and Herbert Blumer (1967). While the pragmatists argued for a communicatively constructed self in order to leave the door open for progress and dialogically-moderated change, the post-modern position chose a similar view of meaning-construction in order to question whether any reliable progress had ever been made in the location of absolutes. Energized by different motives, both paradigms fall short of explaining what it is that 'emotivates' a person or a collective across national and cultural boundaries.

2.11 Even an attempt to question the reliability of 'knowledge' left us unequipped to explain human emotion. Michel Foucault spent volumes exposing how power and knowledge are interconnected (Foucault [1966] $1970,1979)$. While partially freeing us from the control of a methodology optimistically positing itself as a fairly reliable science, he did not come close to answering some of the questions that continue to trouble social theory. While Foucault's work subsequently inspired thoughtful research investigating the role of power in the 'shaping' of the private self and the 'governance' of the soul (Rose, 1985, 1989, 1998), we still need to learn what creates the desire for power and the roles played by those altruistic pro-social sentiments that contradict our historical loss of heart. In Rose's astute study of the colonization of the workplace and the family by experts (1989), what is it that makes the expert want to prescribe to others how they should live? Do political and economic forces form the expert as one would form an inanimate being, or does the would-be expert emerge from their childhood and early youth with a predisposition for priestly functions? If they do arrive with a predisposition to dominate and manage, what gives them that desire?

2.12 Similarly generous dispensations of Nietzschean suspicion are also embedded in the poststructuralist theories. Although Jacques Derrida showed us that words have the power of mesmerizing and misleading (1967a, 1967b, [1967] 1989M), a subsequent doctrinaire (and perhaps excessive) application of his method of 'deconstruction' prevented us from distinguishing between the arbitrary and the universal, an important distinction necessary for the establishment of an ideologically and emotionally informed sociology.

2.13 Nor was a more satisfactory answer to the above issues provided by Jurgen Habermas who tried to revive the Enlightenment promise of dialogical fairness (1987, [1987] 1989, 1990, 1994). He fell a little short of explaining the anatomy of emotional need and the consequences of its distortion. Like Mead ([1934] 1967), he held an overly optimistic view of how situational definitions and mutual experiences have the potential of regulating and decreasing outright conflict. While Habermas did provide a prescription for an ideal dialogic situation (a major accomplishment in the area of communication ethics) he paid insufficient attention to the emotional biographies that prevent subjects from respecting one another's claims in the first place or move them to escalating anger when dialogue does not produce consensus. This goal-oriented view of the social left much unsaid about the stubborn personal and tribal self-justifications that follow from wounded pride and/or unrequited love.

2.14 Norbert Elias, whose works have taken particular account of human emotion, did attempt to free his work from the 'individual' vs. 'society' dichotomy. In What is Sociology (Elias [1970] 1978) Elias cautioned that both down to up and up to down theories missed the fact that all social life is a network of interdependencies out of which emerge immeasurable social permutations. He considered it unproductive and misleading to speak of 'individuals' and 'society' as separate and disembodied categories of experience. Yet, his reluctance to separate the private from the public did not lead him to discovering what may have been previously hidden from view at the private level. Focusing on 'processes' he came up short when time came to enumerate the costs of socialization.

2.15 In his magisterial study of conduct and manners, The Civilizing Process ([1939] 1978, [1939] 1982), Elias investigated how 'civilized' (emotionally restrained) behaviour in the West was connected to increasing inhibitions of primary emotions; however, he concluded that the social system had a way of stabilizing itself despite the heart-breaking psychological amputations of the familial and cultural socialization process 
([1939] 1982: 244). Associating 'shame' with the development of manners and the restriction of violence, he did not dwell enough on the important role played by emotional pain in situations not governed by a social codex. This prevented Elias from mapping out a sociologically and psychologically satisfactory narrative regarding the nature of human emotional needs, the full consequences of their denial or repression, and the relationship between emotional distortion at the personal level and social history at the collective level (Davetian, 2005). While he attempted to show that human society is the product of biological and learned behaviours that somehow come together within a 'configuration,' he did not sufficiently research the actual emotional lives of the subjects who lived in the various eras he researched. Little was revealed about love, intimacy, fear and loneliness, personal emotions that, as Theodore Zeldin has argued (1982), play a central role in the creation of history.

2.16 Even the American interactionists who sought to explain face to face interaction---Charles Horton Cooley and Erving Goffman being the most notable of them---did not go to the bodily origins of the words they were using. Words such as 'embarrassment,' 'face,' 'mortification,' and 'pride' were used with considerable sociological detachment, leaving us no closer to understanding the core of the socialization process and the manner in which personal biographies have a profound influence on larger social processes. The closest Cooley came to a sociology of emotions was when he described 'mortification' as 'some sort of self-feeling' (Cooley 1902: 184). He succeeded, like Herbert Mead ([1934] 1967) and Herbert Blumer (1969), in showing how the self emerges through social interaction, but did not provide a reliable measure of distorted and undistorted social interactions and their causes.

2.17 As for Goffman, he provided a magisterial explanation of how individuals are bound by performance rituals designed to preserve face and avoid unsettling embarrassments $(1959,1967)$, but he did not specify why it is that one individual will fall to pieces when an audience discounts their presented self while another, in a similar position, shakes off the criticism and carries right on with little embarrassment or self-blame. Had Goffman studied emotions and the personal biographies of children more closely he might have provided a more inclusive explanation of the emotional anatomy of self-esteem, its grounding in bodily feelings, and its considerable role in adult social processes.

2.18 All told, the symbolic interactionsits and ethnomethodologists did not sufficiently take into account the bodily aspect of interaction rituals and the manner in which emotions are grounded in a body governed by neurological processes. They assigned considerable agency to the act of 'defining a situation' and the taking on of roles but did not investigate enough how prototypic emotional reactions emerging from personal biographies could determine (and subvert) the manner in which a situation is defined or a role fulfilled. While they added to our appreciation of the action-bound 'institutional self' much remained unsaid about the primary affects that play an important role in the formation, maintenance and justification of the private self and its impulsive and indirect influence on the social.

2.19 Noting this excessive reliance on 'role analysis,' Jack D. Douglas argued very early on in the 1970's that feelings can very easily overwhelm norms and that they are very often part and parcel of social acts even though they lie buried beneath intellectual rationalizations (1975). This same appreciation of 'feeling acts' was later embedded in the work of Randall Collins, who similarly argued for an understanding of the role played by emotions in interaction rituals in which individuals use their own emotions to monitor the emotions of others $(1981,1986,2004)$. They and more recent theorists have cleared the way for a sociology of the emotions that is now a growing and vital part of the discipline.

\section{Progress in an Emotionally Informed Sociology}

3.1 Fortunately for those of us working on the elusive connections between private lives and social outcomes, an encouraging amount of work has been done of late on the 'sociology of emotions.' While it is regrettable that the study of emotions should be a specialty rather than a body of knowledge informing all sociological specialties---historical and economic studies being not the least of them---it is an encouraging start.

3.2 One work that seems most helpful to the reconciling of human personality and social organization is Jonathan H. Turner's On the Origins of Human Emotion (2000). Turner prepares the ground for his subsequent The Sociology of Emotions (Turner and Stets, 2005) by providing a detailed discussion of primary and secondary emotions and the neurological apparatus that connects emotions and thoughts. Turner's Darwin-inspired narrative provides an affective as well as biological map of what is involved in the creation of a social environment. Of particular interest are two sections, The Emotional Repertoire of Humans (66-84), in which Turner presents a great amount of research done in various disciplines on a typology of primary and secondary human emotions, and, The Neurology of Human Emotions (85-118), in which Turner presents convincing evidence on the neurological connections between thought and feeling processes. He concludes that language cannot in and of itself explain human behaviour: 
True, learning is the key to activating humans' innate potential for using and understanding emotional syntax and to invoking the relevant emotionally ordered stocks of knowledge but learning alone cannot explain humans' incredible facility with emotions (133).

3.3 Turner's work indicates that there are certain emotions that are socially influenced (of the secondary order) and certain ones (of the primary order) that are wired into the neurological apparatus of the person. At the theoretical level, this suggests that social theories that focus exclusively on socially constructed social norms and actions gloss over the deeper solar-plexus regions of social identity and social outcomes. It would seem that emotions do not need words in order to exist.

3.4 Jack Barbalet, another important contributor to the growing literature on the 'sociology of emotions,' has similarly argued that, although emotions can be culturally affected, they possess a social structure of their own and play an important role in determining the type of actions taken in response to social events (1998). P.E.S. Freund also cautions that an exclusively social-constructionist view of the social risks ignoring the bodily reality of emotions, thereby producing a further split between organismic and social explanations of society $(1982,1989,1990)$. J. Harré, however, argues against an overly physiological view of emotions; he cautions that a 'bodily feeling is often the somatic expression to oneself of the taking of a moral position' (1991: 143). Unable to completely deny the existence of bodily reactions, the social constructionist vewpoint (1986) attempts to claim that it is the language game or moral position that sets in play an emotional reaction; certainly, this view leaves no room for the possibility that emotions may be stored in the body and accumulate over a period of time, thereby rendering an individual prone to one word game or moral position rather than another.

3.5 Also instructive is the rich body of work done by Thomas J. Scheff. He has examined the phenomenon of shame and its vital role in the development of functional and dysfunctional social bonds $(1985,1987$, 1988, 1990, 1994a, 1994b, 1997). Scheff has probed at the experiencing of 'shame' and tried to show the central role it plays in conflict. Although he considers shame 'the master emotion' and recognizes the full spectrum of human emotions, Scheff does not distinguish between an overload of emotions originating from childhood experiences and emotions used in the present as adaptive responses to the social. Further work needs to be done to determine what lies under shame and whether anger and escalating violence are processes in and of themselves, or, defenses against deeper primal emotions such as sadness. The distinction is not inconsequential because the answers we obtain would conceivably refine our understanding of conflict in a variety of social arenas.

3.6 It is not the purpose of this article to discuss all the work being done in the sociology of emotions, but to indicate that progress is being made. This growing body of work includes Simon Williams's excellent review of the philosophical, theoretical and empirical issues embedded in a sociology of emotions (2001) and Nicholas Rose's studies of how power, personhood and the governing of the social self are incalculably linked $(1985,1989,1998)$. Particularly noteworthy is the anthropologist Richard H. Wills's Human Instincts, Everyday Life, And The Brain: A paradigm for understanding behaviour (Vol. 1, 1998, Vol. 2, 2002). Basing himself on the concept that much of human behaviour involves the exchange of emotional and material resources, Wills has produced an atlas of human behaviour that shows the varieties of situations that result from emotion management. The work contains no less than 2,272 documented observations of interactions and conversations.

3.7 Other primary works arguing for a re-embodiment of social analysis include the works of Arlie $\mathrm{H}$. Hochschild (1975, 1975, 1983, [1989] 1997, 1997), Nick Crossley (1998, 2001), Richard Sennett (1990), Bendelow and Williams (1997), Tangney and Dearing (2002), Williams (2001), Baumeister and Wotman (1992), Juliette Greco (2001), and Chris Yuill (2004).

3.8 All the above studies agree that emotions play a central role in social life. What is in contention, however, is whether what we call 'emotions' are socially constructed and variable across cultural boundaries or whether they are biological realities governed by forces not dependent on the influences of language or learning. While proponents of both views would agree that many of our secondary emotions (i.e. pride, embarrassment) are socially influenced they part ways when it comes time to determining whether there is a 'primal' well from which emotions are drawn out into the social arena. I hope to argue that there is a well and that this well plays a large role in determining the geist of a culture and whether or not its citizens feel fulfilled within their social environments. I also hope to argue that personal biographies are the complicating factors in the realization of social and moral ideals; these emotional biographies start at the pre-linguistic level (birth to 2 years of age) and continue right into old age.

\section{The Pain Factor}

There is little conjunction of truth and social 'reality.' Around us are pseudo-events, to which we adjust with a false consciousness adapted to see these events as true and real, and even 
as beautiful. In the society of men the truth resides now less in what things are than in what they are not -- R.D. Laing (1967:1).

If you must, kiss them once on the forehead when they say good night. Shake hands with them in the morning' -- John B. Watson on child-rearing (Watson [1928] 1972: 81-82)

4.1 In a thought-provoking article entitled 'Sociological Introspection and Emotional Experience' (1991), Carolyn Ellis questions whether sociologists who have an overly socialized bias can study emotions in a satisfactory way. She suggests that we should protect ourselves from over-intellectualizing the feelings of the people we study by practicing some introspection. Ellis's suggestion raises some controversial questions: Can we, who are habituated to dealing with abstractions, manage to transcend our own mind-set while studying the topic of bodily emotions? Or are we somewhat over-cerebral, slightly cut off from our own emotional selves because of the burden of our intellectual tasks? Can we 'think' of emotions in a productive and real way, or, must we 'feel' our way into our topic?

4.2 I certainly had to confront these questions when I encountered the evidence I am about to share. It was too simple; perhaps even too conclusive. It required me to rethink my entire understanding of society and progress, not to mention my own identity as a person. It certainly made me uneasy with the entire project of 'theorizing' society for I came to suspect that much of history, economics and culture is a double-edged sword, arising out of human misery yet also contributing to human greatness and then creating more misery in the end. I came to stop thinking in terms of a sociology of emotions and begin thinking in terms of an emotionally conscious sociology.

4.3 In a book published in 1970 (perhaps over dramatically entitled, The Primal Scream---a title that moved many social scientists to dismiss the work without reading it), Arthur Janov documented a therapeutic process that seemed to be helping adults release emotional pain supposedly originating from childhood experience. The book struck a cord in a generation wondering why it felt so much frustration and yearning; it became an instant best seller and was soon translated into several languages. Subsequent books and scholarly articles by Janov have included Primal Man: The New Consciousness (Janov and Holden, 1975), The Biology of Love (2000), and Words Won't Do It (Forthcoming).

4.4 While Sigmund Freud (1930 [1945]) and Wilhelm Reich (1950 [1964]) had written extensively about emotions and the compensatory character structures that arise out of frustration and repression, they had stopped one step short of discovering the full extent of a person's feeling self and the social consequences of the suppression of that self. Freud realized late in his career that remembering trauma without expressing the emotions registered at the time of the occurrence of the trauma was not curative. Janov stumbled on the empirical evidence required to support Freud's belated conclusion. What occurred in the late 1960's in the office of this American family therapist provides a wealth of insight into the body, the anatomy of emotions and the wider social that is the habitat of thinking/feeling individuals.

4.5 During one of his regular talk-therapy groups, Janov was listening to one of his clients describe how he had been impressed by an off-Broadway play in which the actors walked around the stage calling out to their 'mommies and daddies.' Janov asked the young man to do the same and call out to his mother and father. The young man demurred at first, but then agreed. As the man began calling out to his mother and father, he suddenly found himself overwhelmed by a heart-wrenching sadness that emerged from him in loud wails. The entire experience was over in less than ten minutes. Although both Janov and the client were very surprised by what had happened, the client reported, 'I made it! I don't know what, but I can feel!' (Janov, 1970: 9-10). The man's parents were not dead and he was in contact with them so this was no mourning for the dead.

4.6 Janov did not understand the meanings of the wails nor why they had suddenly overwhelmed his client. The client was a functioning professional, with no history of mental illness. A few months later, Janov had the opportunity to learn more about what had happened with his first client. The same event occurred with another man. After crying with great depth and force, the client ended the session reporting that his life seemed to have fallen into place and that he felt his whole 'sensorium' had opened up (10).

4.7 Janov tried slight modifications with other clients and obtained the same results. Out of this initial discovery, he developed a psychotherapy process that helped individuals remember and regain access to feelings that they had previously kept suppressed. The process differed radically from conventional psychoanalytic and behaviour modification therapies that aimed to help a person function better by changing their behaviour or their view of the world. Janov concluded that what caused a permanent cure of discontent was the full experiencing of repressed sadness, fear and anger.

4.8 Instead of being asked to embark on an analytical conversation with a therapist, his clients were encouraged to 'let go' and feel their emotional reaction to events that were occurring in their lives. This entry 
into emotion at the level of the present provided increased access to feelings registered and suppressed in the past. Alternatively, clients gained access to their pain by recounting painful past events (1975: 187). This 're-living' of old pain, along with the expression of the emotions and words that had been originally restrained (i.e. 'Dad, would you stop reading your newspaper and pay attention to me!!'), seemed to have a healing effect that was radically different from the temporary highs reported by individuals undergoing shortterm motivational therapy. This was no ordinary abreactive experience. Janovs clients reported feeling themselves at the precise age they had been when the painful experience had occurred and been repressed (140-141). What seemed to have caused the pain was outright abuse, mild and strong neglect, as well as excessive parental expectations; many individuals who had attentive parents felt hurt that the love they received was always conditional.

4.9 Changes experienced by individuals who went through this process seemed irreversible; they encourage us to reconsider our standing explanations of our social nature. The reports of Janovs clients suggest that most of our observations of human nature are made following the traumas of socialization. Lacking some way of reversing these traumas has made it impossible to learn from the insights of people who are clear of pain. In other words we know humans in their 'second nature,' a nature developed as a defense against experiencing the pain of having one's original nature compromised. Rousseau provided a philosophical statement on the costs of faulty socialization and the human condition in Emile ([1761] 1979), his perceptive study of how difficult it is to raise a child who is clear of emotional and value-laden perturbations. Janov provided the empirical evidence required to give credence to Rousseau's emotional idealism.

4.10 Very importantly, Janov's 'post-primal' clients felt liberated to express feelings in the present with new clarity and honesty. There was a marked decrease in anger and uncivil reactions in individuals who had terminated a substantial portion of their feeling work. This even applied to extremely anti-social personalities. 'Post-primal' individuals were less defensive, less self-seeking and more able to minister to the needs of others. Above all, they were less afraid of the disapproval of others. No longer transferring the need for an approving parent onto substitute parent figures located in their social relations, they exhibited the ability to be emotionally honest and integral under pressure. Also interesting was the fact that once they were in their feelings issues of gender were no longer apparent; men cried as freely, deeply and tenderly as women. Most striking was the fact that every individual experiencing this therapy was able to gain access to and experience feelings registered in the body prior to the learning of language (birth to 2 years of age); in many instances, when an emotion from this distant past was being felt, the body revealed the signs of the original traumatism (i.e. bruises where there had been an injury). It would seem that the body has a memory system not dependent on language. (Janov and Holden, 1975: 313, 353, 519). Also instructive was the fact that individuals in nearly 35 countries underwent this therapy, indicating that emotional pain is a universal reality.

4.11 Many of the experiments conducted by social psychologists would not have worked on Janovs 'postprimal' clients, certainly not Stanley Milgram's experiments on obedience to authority (1983) nor Solomon Asch's study on conformity and perception (1958). Milgram's and Asch's experiments seemed to reveal little about the 'primal' nature of the human but much about the consequences of its distortion. I tried to replicate Asch's experiment on a group of post-primal patients in 1990 but did not obtain a single result that confirmed Asch's theory regarding human susceptibility to group pressure. The subjects were in touch with their own feeling consciousness and trusted it above all other considerations.

4.12 'Post-primal' individuals also became uninterested in acquiring power or riches at the expense of others, even though many of them reported possessing such wants prior to their feeling experiences. Feeling repressed emotions seemed to give them an emotional intelligence equipped with a built-in 'conscience.' There seemed to be a connection between recovering 'consciousness' and developing a spontaneous 'ethical conscience' (Janov and Holden,1975: 38-39, 270-271). Having become honest with themselves (their pain) they became spontaneously honest with others. They seemed to have discovered their 'real' needs and were no longer given to symbolizing and projecting them by seeking substitute gratification. Repeatedly, Janovs clients specified that previously they had wanted what did they did not need as way of anaesthetizing their pain...they arrived at a clear distinction between 'needs' and 'wants.'

4.13 What was surprising about Janovs work with his clients was that when a client regained their composure they did not look any worse off for having had the feeling experience. Janovs work debunked the centuries-old belief that loss of control over strong emotions would lead to mental illness or social chaos. Feeling an emotion in a safe environment and in connection to its original precipitating event seemed to actually heal mental and emotional disturbance.

4.14 Janov's discovery was an important milestone in cultural history. At no time in all of Western civilization had any philosopher or scientist developed an environment in which individuals could fully experience repressed pain and be done with it. While literature and philosophy and psychology always referred to it, the standing assumption was that there was nothing that could be done. One shed tears as a 
temporary relief. One ended up in a madhouse. But one did not cure one's 'human condition.' It was understandable, therefore, that the majority of psychologists who heard of Janovs work, while they did eventually accept that emotions should be an integral part of the therapeutic process, rejected Janovs call for a radical revision of psychological practice. His use of the word 'cure' was met with skepticism in a profession habituated to 'treating' symptoms. It took a while for the box of tissue paper to become a standard staple of the therapy office.

4.15 Janov's discovery was validated by pre-existing neurological research confirming the capacity of the human brain to store away memory and emotion out of consciousness (Penfield, 1950: 45, 50-51; Melzack and Wall, 1965: 971-979; Melzack and Scott, 1957: 155-161; Herrick, 1926: 91). In their own right, Janov and the neurologist Michael Holden published the results of neurological tests given to individuals prior and after therapy (1975). The tests revealed that the physical vital signs (including E.E.G.'s) and overall health of their clients had permanently changed following their feeling experience (i.e. permanently lower blood pressure, lower pulse, lower body temperature, increase alpha activity in the brain) (471-508). Further commentary by Janov regarding the implications of his findings can be found at:

http://www.primaltherapycom/FRAMESbasic/randomthoughtsFrame.htm

4.16 Janov arrived on the crest of the emotional awakening that characterized the generations of the 1960's1980 's. He witnessed that the freeing of emotional restraints, in a proper and safe setting, had no decivilizing effect. While the 'unidimensional' person who had so perturbed Herbert Marcuse (1964) and William Whyte (1956) was robotic and unfeeling, irrational in their search for a disciplined conformist rationality, the feeling individual was able to practice insight, judging situations according to their nature and merit rather than according to an a-priori emotional and ideological predisposition (neurotic prejudice?).

4.17 It is not my purpose to suggest that Janov's type of therapy is better than other therapies nor suggest that sociology should become a therapeutic science. In fact, there are considerable cautions required, since the experiencing of deep emotional pain dating back to early childhood can render an individual dysfunctional if carried out improperly. I am only trying to point to the existence of that pain and the fact that emotions (distorted as well as authentic) have a salient influence on individual personality and the geist of a culture.

4.18 In fact, the discovery that emotional pain is a biological reality raises some important questions about the relationship between the private and public realms. If, as Janovs discovery suggests, pain cannot be permanently eradicated through the alteration of thought or the adoption of compensatory ideology, then its presence may be acting as a contaminating agent in private and public communications and actions.

\section{Some Implications}

5.1 The discovery that emotional pain emanating from childhood continues to exert pressure on the adult suggests a highly active and sensitized conduit between the 'private' and 'institutional' selves. This said, however, it is important to remember that this interaction is two-directional. The problem with the origins of sociology and psychology is that each discipline observed the direction taken by the other and then attempted to formulate its own unique uni-directional explanations. Psychologists went 'into' the human while sociologists went 'out' into the social, not consulting each other yet criticizing each other for not taking more information into account! Over 140 years after the passing of Comte, sociologists and psychologist continue to hardly talk with one another or read one another's journals.

5.2 In his study of suicide Durkheim came close to providing a satisfactory explanation of this rich bidirectional relationship between sentiment at the individual level and action at the social level (Jones, 1986: 82-114). Unfortunately, he became influenced by his need to avoid an explanation that was exclusively based on individual psychology. Observing that different religious groups in the same region had differing rates of suicide, he concluded that the degree to which social bonds were tight or loose had a salient influence on the suicide rate. He further refined his categorization of social influences by determining that marital status and age had a further influence on the propensity for suicide. What remained unclear was why certain individuals in one category would kill themselves while others in the same category would not. Ideally, he should have provided a social as well as individual explanation; this would have led to further and profitable theorizing about the psychosocial nature of social bonds and the degree to which pain renders individuals vulnerable to additional social pressures. His theory of moral education similarly attempted to find public solutions for perturbations emanating from more micro-social situations. He believed that moral education would counteract the negative effects of individualism (Durkheim 1961). However, while moral education does restrain individuals from engaging in socially destructive behaviour, it cannot provide a society with a clean emotional slate. The best that can be hoped for is that an individual will learn to be moral and given to ministering to the comforts of others despite his or her own unfulfilled emotional needs, at best an 'ideal speech situation' (Habermas, 1987). The behavioural repression facilitated by 'morality' is 
offered up as a defense against the corrosive and destructive effects of feeling repression; it improves the situation by defining the manner in which self-serving feelings are to be restrained at the social level, but does not free the social from emotional and moral 'simulations' that somehow do not satisfy (Baudrillard, 1998).

5.3 Despite moral exhortations and panics, emotions have the power of over-riding social norms and spilling over from the private self into the institutional self, affecting judgment and the number of emotional 'fixes' that will be required in order to keep out of consciousness previously stored sadness, fear, anger and frustration. These fixes can include a variety of behaviours, including self-deprecation, narcissism, cruelty and vengeance, exaggerated tribalism, irrational justifications of personal and collective acts, and an overall propensity towards sentimental and material greed. Pain-ridden persons may have few options: to feel the pain or to run from it by distracting themselves and draining their overload of pain through spurious satisfactions or conflicted encounters doomed to produce unsatisfying outcomes.

5.4 Now, if it is true that emotional pain accumulates in the human body, forcing its victim to seek relief, we may have a proficient way of deepening and broadening our view of a variety of social topics, including consumption, media, civil and international conflict, marriage and divorce, juvenile and adult crime, civility and incivility, gender relations, economic trends and political movements, and, of course, face to face interaction rituals. Certainly, a deeper knowledge of emotional pain and the defenses adopted to repress it would help us better evaluate to what extent the 'rationalization' of social life is an inevitable product of modes of production and social organization and to what extent it is the result of 'excessive repression' (Marcuse, 1955: 31-32).

5.5 The 'pain factor' also has some important bearing on cultural and linguistic theory. It would seem that, in and of itself, language does not create emotions. It simply allows for their expression, symbolization and repression (i.e. 'I was so embarrassed,' instead of 'I came close to feeling just how rejected and worthless I really feel deep inside me'). Cultural influences, mediated by language, may determine how a painful or joyful sentiment is to be expressed (Smith and Bond, 1998; Schwartz and Bilsky, 1990; Hofstede, 1980, 1983; Hall and Hall, 1990). They may also determine to what extent dissatisfaction is to be expressed, if at all (Davetian, 2005; Smith and Bond, 1998). But these influences cannot eliminate the existence of primary universal emotions (Ekman, 1972; Ekman et al. 1987; Turner, 2000). In fact, 'shame,' the major topic of Elias's and Scheffs work, may be a culturally formed defense against the deeper root emotion of sadness and rejection. If shamed individuals tend to offer justifications or reparations, as amply demonstrated by Goffman and Scheff, they may be doing so in order to avoid the feelings to which shame renders them vulnerable. Although the specifications of behaviours considered shameful vary from one culture to another, the emotion of pain underlying shame remains a universal phenomenon and is connected to the fear of not acquiring love and validation of personal worth.

5.6 We are at a paradoxical juncture in the development of Western and global civilization. While, on one hand, a variety of social movements have allowed us to be more vocal about our civil and emotional needs (and more loyal towards them---hence the idea of a 'society of rights' and 'high individualism'), many are forced at the economic level to deny those needs and fit in with a corporate bottom-line culture that measures human life not from the long-term view of the personal and general good but from the perspective of maximizing profit in the short term. At the level of family, individuals are being allowed more than before to express their needs (real and distorted); yet, at the public level, a mentality of competition and scarcity is demanding self-restraint and submission to corporate imperatives. This disjuncture is amply demonstrated in Arlie Hochschild's seminal study, The Managed Heart: Commercialization of Human Feeling (1983), an ethnography of people in service occupations who must always put up a cheerful accommodating face.

5.7 The long-range cost to this brave new society divided against its own feeling consciousness is yet to be known, but the issue needs to be addressed by social theory, for our standing conceptions of 'society' are being tested by the paradoxes of contemporary reality. As suggested by Nicholas Gane (Beer and Gane, 2004), we need to develop our understanding of 'time' and 'space' and the effects that 'digital transformations' are having on human identity; but we also need to increase our understanding of the 'feeling bodies' that live within these cultures of change.

5.8 So, our search for an emancipatory social compromise capable of accommodating competing claims and the contingencies of a high-risk paradoxical society should not inhibit our need to consider certain worthy propositions that emerge from our conception of the self as a distinct emotional entity standing within as well as outside social constructs. Some of these propositions include: 1) Beyond the primal need for survival, a very important need of the human being is to be loved and to love. The need to accomplish and distinguish oneself comes later once the primary needs have been met. Comte might have come close to this realization when he spoke of a religion of love, risking the ridicule of his more emotionally restrained successors; perhaps he had confronted his own pain and was expressing it by pleading for an integral 
humanity; 2) When the need for love remains unfulfilled at the private level of the family (or thwarted by 'public troubles') the individual becomes disposed to gravitating towards acts 'symbolizing' his or her distress; these acts have an immense influence on the social, sometimes positive (i.e. 'Let me build a bridge so I can feel better') and sometimes very negative (i.e. 'Let me start a big war to show everyone I am not as powerless as others think'); 3) The more there is an easing of repression over suppressed emotions, the more become the opportunities for authentic emotional experiencing as well as the projection and displacement of emotional overload. A society in disarray can be extremely close to a new and more stable level of integration just as it can be close to disintegration; the 'civilizing process,' therefore, has to be evaluated from functional as well as affective points of view, for what may appear satisfactory in one framework may be cause for worry in another; 4) Being populated by feeling individuals, all social systems are in a contagious relationship with their inhabitants; a society of emotionally agitated (overloaded) individuals is a disturbed society, just as a society repressed by ideologies of ultra-rationalization can stultify the emotional lives of its citizens, setting the stage for future reactionary perturbations.

$5.9 \mathrm{It}$ is, therefore, not entirely unreasonable to suggest that a society can be affected by the 'childhoods' of its citizens. The political, cultural and economic history of a society, and the biographies of its members, are in a compounded relationship with one another and form a 'configuration' of effects (Elias, [1970] 1978). Understanding these effects becomes even more urgent when we consider that new media technologies and trans-national economies are linking regions that possess very different emotional biographies and interaction codes. We need some way of telling the difference between globalization and contagion, and between cultural relativity and human universals. During a four-year study of civility in three countries (the U.K., France and the U.S.A.), I discovered that each culture not only had different levels of individualism and communalism, but also possessed different standards regarding the degree of dissatisfaction and emotional pain that could be expressed in private and public without the earning of censure. Taking into account primary and secondary emotions, as well as emotional defense processes, helped me better understand important differences in family organization, state institutions and educational systems (2005).

5.10 To further illustrate the possibilities of an emotionally informed sociology, I would like to share an experience I had during a research trip to Iran in 2000. I went there to study civility rituals and to better understand anti-American sentiments in that country (Davetian 2000a, 2000b).

5.11 During my field study I discovered that there was considerable anti-American sentiment. Yet, I very often came up with very incomplete feedback whenever I tried to discuss American policy with citizens. I gradually discovered that anti-American sentiments in that country could be better understood by probing at the manner in which Iranians negotiated shame, particularly in regards to pre-marital sexual practices. When that factor was taken into account, I was led to the unexpected discovery that a considerable portion of anti-American sentiment was not directed at America's political and economic policies but at the possibility that liberal American (and European) sexual practices would colonize Iranian family values and practices.

5.12 There seemed to be a direct correlation between sexual conservatism and anti-American sentiment. Those Iranians who welcomed liberal family structures and liberal sexual norms were much more given to being pro-American; they were found in the ranks of the poor and the rich. Moreover, some additional probing revealed that many conservative Iranians agreed with one another that they were not comfortable with American policy, not due to any massive grass-roots political agenda but in order to demonstrate to each other that they were moral and loyal to the public shame standards of their culture. In private, however, they demonstrated a far more relaxed and humourous attitude. Further probing revealed even more interesting insights; a major source of contention with American values was the degree of restraint demanded in American culture towards the expression of pain; many Iranians who had access to satellite television felt that the Americans were repressed and inhibited in the emotional realm (Davetian 2000b). Many of them were dumb-founded that people in the West restrained their emotions at funerals.

5.13 It would seem that all international conflict is not politically and economically motivated. As Scheff has demonstrated, a tremendous amount of escalating conflict is connected to emotions that are not declared on the political agenda (Scheff, 1994a). In order to discover them one has to remain attuned to the existence of primary emotions and the defenses that are used to conceal or rationalize them. So we need to develop a sociology that is capable of being 'situational' as well as 'biographical,' even if this requires that we become more tolerant of 'paradoxical' findings.

5.14 We have come a long way since John B. Watson, the father of behavioural psychology, advised mothers to restrain themselves from kissing their children (Watson [1928] 1972: 81-82). The fact that we are now speaking of a sociology of emotions demonstrates the degree to which our awareness of human need and equity has evolved. This should be encouraging for those of us who are writing social theory, for we are beginning to see that the 'self---although it has had a rough time of it in the 20th century---is still alive and may conceivably figure prominently in the building of a society in which caring, respect, dignity and equity 
are core values, at the private as well as institutional levels. An emotionally conscious sociology may be the needed frontier for helping us reconcile our need for diversity and coherence.

\section{References}

ASCH, S. (1958) "Effects of group pressure on the modification and distortion,"

in E. E. Maccoby, T. M. Newcomb, \& E. L. Hartley (editors), Readings in Social Psychology. New York: Holt, Rinehart, \& Winston.

BARBALET, Jack (ed.) (1998) Emotion, Social Theory and Social Structure . Cambridge: Cambridge University Press.

BAUDRILLARD, Jean (1998) Selected Writings, edited by Mark Poster. Stanford: Stanford University Press, pp. 166-184.

BAUMEISTER, Roy F. and Sara R. Wotman (1992) Breaking Hearts - The Two Sides of Unrequited Love . New York: Guilford Press.

BEER, David and Nicholas Gane (2004) 'Back to the Future of Social Theory - An Interview with Nicholas Gane,' Sociological Research Online, Vol. 9, No. 4.

http://www.socresonline.org.uk/9/4/beer/beer.html

BENDELOW, Gillian and Simon J. Williams (eds.) (1997) Emotions in Social Life - Critical themes and Contemporary Issues. London: Taylor and Francis.

BLUMER, Herbert (1969) Symbolic Interactionism: Perspectives and Method. Berkeley: University of California Press.

CAMPBELL, Colin ([1987] 1993) The Romantic Ethic and the Spirit of Modern Consumerism .

Oxford: Blackwell Publishers.

COLLINS, Randall (1981) 'On the Microfoundations of Macrosociology,' American Journal of Sociology, 86(5), pp. 984-1014.

COLLINS, Randall (1986) 'Is 1980's Sociology in the Doldrums?' American Journal of Sociology, 91(6), pp. 1336-1355.

COLLINS, Randall (2004) Interaction ritual chains. Oxford: Princeton University Press.

COOLEY, Charles Horton (1909) Social Organization. New York: Scribner's.

CROSSLEY, Nick (1998) 'Emotions and Communicative Action,' in G. Bendelow and S. J. Williams (editors), Emotions in Social Life: Critical Themes and Contemporary Issues. London: Routledge.

CROSSLEY, Nick (2001) The Social Body: Habit, Identity and Desire . London: Sage.

DAVETIAN. Benet (1996) 'Emotions and Social Theory.' Paper presented at Graduate Conference, Department of Sociology and Anthropology, Concordia University, Montreal.

DAVETIAN, Benet (2000a) 'Sociology of Courtesy.' Paper presented at the International

Social Theory Consortium, July 7, 2000. East Sussex, U.K.

DAVETIAN, Benet (2000b) 'Moral tensions Between Islamic and Western cultures.

Towards a sociology of East and West in the wake of September 11,' Sociological

Research Online, Vol. 6, No. 3. http://www.socresonline.org.uk/6/3/davetian.html.

DAVETIAN, Benet (2005) Civility: A Multi-Cultural Genealogy. Publication

forthcoming.

DEKKER, George (1978) Cooleridge and the Literature of Sensibility . London: Vision 
Press.

DERRIDA, Jacques (1967a) De la Grammatologie. Paris: Minuit.

DERRIDA, Jacques (1967b) L'Ecriture et la Différence. Paris: Seuil.

DERRIDA, Jacques ([1967] 1989) La Voix et le phénomène. Paris: Presses universitaires de France.

DESCARTES, R. (1968) Discourse on Method and the Meditations. Harmondsworth: Penguin.

DOUGLAS, Jack D. (1977) 'Existential Sociology,' in Jack D. Douglas and John M. Johnson (editors), Existential Sociology. New York: Cambridge University Press, pp. 3-73.

DURKHEIM, Emile ([1895] 1982) The Rules of Sociological Method. London: Macmillan.

DURKHEIM, Emile (1961) Durkheim, Emile. Moral Education: A Study in Theory and Application of the Sociology of Education. New York: Free Press, 1961.

EKMAN, P. (1972) 'Universals and cultural differences in facial expressions of emotion,'

Science, 164, pp. 85-88.

EKMAN, P. et al. (1987) 'Universals and cultural differences in the judgments of facial expressions of emotion,' Journal of Personality and Social Psychology , 53, pp. 712-717.

ELIAS, Norbert ([1939] 1978) The Civilizing Process, Vol. 1: The History of Manners , trans. Edmund Jephcott. Oxford: Basil Blackwell.

ELIAS, Norbert ([1939] 1982) The Civilizing Process, Vol. 2: State Formation and Civilization, translated by Edmund Jephcott. Oxford: Basil Blackwell.

ELIAS, Norbert ([1970] 1978) What is Sociology? London: Hutchinson

ELLIS, Carolyn (1991) 'Sociological Introspection and Emotional Experience,' Symbolic Interaction, 14(1), pp. 23-50.

FOUCAULT, Michel ([1966] 1970) The Order of Things (Les mots et les choses). New York: Pantheon Books.

FOUCAULT, Michel (1979) Discipline and Punish: The Birth of the Modern Prison . Translated

by Alan Sheridan. New York: Vintage Books.

FREUD, Sigmund ([1930] 1945) Civilization and its Discontents, trans. James Strachey.

Chicago: Great Books Foundation.

FREUND, P.E.S. (1982) The Civilized Body - Social domination, Control and Health . Philadelphia: Temple University Press.

FREUND, P.E.S. (1989) 'Bringing Society Back into the Body - Understanding Socialized Human Nature,' Theory and Society, 17 (6), pp. 839-864.

FREUND, P.E.S. (1990) 'The Expressive Body - A Common Ground for the Sociology of Emotions and Health and IIIness,' Sociology of Health and IIIness , 12 (4), pp. 452-477.

GAME, A. and A. Metcalfe (1996) Passionate Sociology. London: Sage.

GANE, Nicholas (ed.) (2004) The future of Social Theory . Sydney (AUS): Continuum Publishing Group.

GIDDENS, Anthony ([1991] 2001) Modernity and Self-Identity . Cambridge: Polity Press.

GOFFMAN, Erving (1959) The Presentation of Self in Everyday Life. Harmondsworth: Penguin Books.

GOFFMAN, Erving (1967) Interactional Ritual. Chicago: Aldine Books.

GRECO, Juliette (2001) 'Inconspicuous anomalies: alexithymia and ethical relations to the self. Health, 5 (4), pp. 471-492. 
HABERMAS, Jurgen (1987) The Theory of Communicative Action, translated by Thomas

McCarthy. Boston, Massachusetts: Beacon Press.

HABERMAS, Jurgen ([1987] 1989) The Philosophical Discourse of Modernity, translated by Frederick Lawrence. Cambridge, Massachusetts: MIT Press.

HABERMAS, Jurgen (1990) Moral Consciousness and Communicative Action . Cambridge,

Massachusetts: MIT Press.

HABERMAS, Jurgen (1994) 'Struggles for Recognition in the Democratic Constitutional States,'

in Multiculturalism, Amy Guttman (editor). Princeton, New Jersey: Princeton University Press.

HALL, Edward T. and Mildred Reed Hall (1990) Understanding Cultural Differences .

Yarmouth, Maine: Intercultural Press.

HAMMOND, Michael (1983) 'The Sociology of Emotions and the History of Social Differentiation,' in Randall Collins (editor), Sociological Theory, San Fransisco, CA: Jossey-Bass Inc., pp. 90-119.

HARRÉ, J. (1986) The Social Construction of Emotions . Oxford: Basil Blackwell.

HARRÉ, R. (1991) Physical Being: A Theory for a Corporeal Psychology . Oxford: Basil

Blackwell.

HERRICK, C. J . (1926.) Brains in Rats and Men. A Survey of the Origin and Biological

Significance of the Cerebral Cortex. Chicago: University of Chicago Press.

HOCHSCHILD, Arlie (1975) 'The Sociology of Feeling and Emotion: Selected Possibilities.' Sociological Inquiry, 45(2-3), pp. 280-307.

HOCHSCHILD, Arlie (1979) 'Emotion Work, Feeling Rules, and Social Structure.' American

Journal of Sociology, 85, pp. 551-575).

HOCHSCHILD, Arlie (1983) The Managed Heart: Commercialization of Human Feeling . Berkeley: University of California Press.

HOCHSCHILD, Arlie ([1989] 1997) The Second Shift. New York: Avon Books.

HOCHSCHILD, Arlie (1997) 'Work: The Great Escape.' New York Times Magazine,

April 20, 1997, 51-55. pp. 81-84.

HOFSTEDE, Geert (1980) Culture's Consequences: International differences in work-related values . Beverley Hills, CA: Sage.

HOFSTEDE, Geert (1983) 'Dimensions of national cultures in fifty countries and three regions,' in J. Deregowski, S. Dzuirawiec, and R. Annis (editors), Expiscations in Cross-cultural Psychology. Lisse, Netherlands: Swetz and Zweitlinger.

JANOV, Arthur (1970) The Primal Scream. New York: Dell.

JANOV, Arthur and Michael Holden (1975) Primal Man. New York: Thomas Y. Crowell.

JANOV, Arthur (2000) The Biology of Love. New York: Prometheus Books.

JANOV, Arthur (Forthcoming) Words Won't Do It.

JONES, Robert Alun (1986) Emile Durkheim: An Introduction to Four Major Works . Beverly Hills, CA: Sage Publications.

KEMPER, Theodore D. (1978) 'Toward a Sociology of Emotions: Some Problems and Some Solutions,' American Sociologist, 13(1), pp. 30-41. 
LAING, R. D. (1967) The Politics of Experience and the Bird of Paradise . New York: Ballantine.

LYOTARD, J.F. (1999) The Postmodern Condition. Manchester: Manchester

University Press.

MARCUSE, Herbert (1955) Eros and civilization: A philosophical inquiry into Freud .

Boston: Beacon

MARCUSE, Herbert (1964) One-Dimensional Man. London: Routledge.

MEAD, George Herbert ([1934] 1967) Mind, Self, and Society. Chicago: University of Chicago Press.

MELZACK, R. and T. H. Scott (1957) 'The Effects of early Experiences on the Response of Pain,' Journal of Comparative Physiological Psychology, Vol. 50, pp. 155-161.

MELZACK, R. and P. Wall (1965) 'Pain Mechanisms: A New Theory,' Science, Vol. 150, pp. 971-979.

MILGRAM, Stanley (1983) Obedience to Authority: An Experimental View. New York: Harper/Collins

PENFIELD, Wilder \& Roberts L. (1959) Speech and Brain Mechanisms. Princeton, New Jersey: Princeton University Press.

REICH, Wilhelm ([1950] 1964) Character Analysis. New York: Viking Press.

ROSE, Nicholas (1985) The Psychological Complex - Psychology, Politics and Society in England 18601939. London: Routledge \& Kegan Paul.

ROSE, Nicholas (1989) Governing the soul - The shaping of the private self . London: Routledge.

ROSE, Nicholas (1998) Inventing our selves: Psychology, power and personhood . Cambridge: Cambridge University Press.

ROUSSEAU, Jean Jacques ([1761] 1979) Emile, translated by Allan Bloom. New York: Basic Books.

SCHEFF, Thomas J. (1985) 'The Primacy of Affect,' American Psychologist, 40(7), pp. 849-850.

SCHEFF, Thomas (1987) 'The shame-rage spiral: A case study of an interminable quarrel,' in H. B. Lewis (editor), The role of shame in symptom formation. Hillsdale, New Jersey: Erlbaum.

SCHEFF, Thomas J. (1988) 'Shame and Conformity: The Deference-Emotion System.' American Sociological Review, 53(3), pp. 395-406.

SCHEFF, Thomas (1990) Microsociology: discourse, emotion and social structure. Chicago: University of Chicago Press.

SCHEFF, Thomas (1994a) Bloody revenge: emotions, nationalism, and war . Oxford: Westview Press.

SCHEFF, Thomas (1994b) 'A Theory of Ethnic Nationalism,' in Craig Calhoun (editor),

Social Theory and the Politics of Identity . Oxford: Blackwell.

SCHEFF, Thomas (1997) Emotions, The Social Bond, and Human Reality: Part/Whole

Analysis. New York: Cambridge University Press.

SCHWARTZ, Shalom and W. Bilsky (1990) 'Toward a Theory of the Universal Content and

Structure of Values: extensions and cross-cultural replications,' Journal of Personality and Social

Psychology, 58, pp. 878-891.

SCOTT, John (2005) 'Sociology and Its Others: Reflections on Disciplinary Specialisation and Fragmentation.' Sociological Research Online, Vol. 10, No 1.

http://www.socresonline.org.uk/10/1/scott.html.

SENNETT, Richard (1977) The Fall of Public Man . Cambridge: Cambridge University Press. 
SENNETT, Richard (1990) The Shaping of the Private Self. London: Routledge.

SHILLING, Chris (1993) The Body and Social Theory . London: Sage.

SIMMEL, Georg ([1908] 1950) The Sociology of George Simmel , trans. K. H. Wolff. Glencoe: III.: Free Press.

SMITH, Peter B. and Michael Harris Bond (1998) Social Psychology Across Cultures . London: Prentice Hall.

SYNNOTT, Anthony (1993) The Body Social . London: Routledge.

TANGNEY, June Price and Ronda L. Dearing (2002) Shame and Guilt. New York: Guilford Press.

TURNER, Bryan (1984) The Body and Society - Explorations in Social Theory . Oxford: Blackwell.

TURNER, Bryan (1992) Regulating Bodies. London: Routledge.

TURNER, Jonathan (2000) On the Origins of Human Emotions. Stanford: Stanford University Press.

TURNER, Jonathan and Jane Stets (2005) The Sociology of Emotions . New York: Cambridge University Press.

WATSON, John B. ([1928] 1972) Psychological Care of Infant and Child . New York: Arno Press.

WEBER, Max (1930) The Protestant Ethic and the Spirit of Capitalism, trans. Talcott Parsons. London: G. Allen and Unwin.

WHYTE, William (1956) The Organization Man. London: Cape.

WILLIAMS, Simon (2001) Emotions and Social Theory. London: SAGE Publications.

WILLS, Richard H. (1998) Human Instincts, Everyday Life, And The Human Brain: A paradigm for understanding behavior. Vol. 1. Charlottetown, Prince Edward Island: Emporium Press.

WILLS, Richard H. (1998) Human Instincts, Everyday Life, And The Human Brain: A paradigm for understanding behavior. Vol. 2. Charlottetown, Prince Edward Island: Emporium Press.

YUILL, Chris (2004) 'Emotions After Dark - a Sociological Impression of the 2003 New York Blackout,' Sociological Research Online, Vol. 9. No. 3. http://www.socresonline.org.uk/9/3/yuill.html.

ZELDIN, Theodore (1982) 'Personal History and the History of Emotions,' Journal of Social History , 15(3), pp. 339-347. 